\title{
4th International Forum on Rheumatoid Arthritis: Great Times Near the Great Wall
}

\author{
David S Pisetsky*
}

Beijing, an incredible city, was the site for the 4th International Forum on Rheumatoid Arthritis (IFRA), an incredible meeting. Professor Zhan-guo Li, Professor of Medicine at Peking University and President of the Asia Pacific League Against Rheumatism, and his co-chairs, Professor Lars Klareskog, Professor of Rheumatology, Karolinska Institutet, and Professor Kazuhiko Yamamoto, Professor of Medicine, University of Tokyo, organized the meeting. They did a terrific job and created a program to showcase the excitement and dynamism of both modern China and modern rheumatology. Professor Li was a great host as hundreds of Chinese rheumatologists packed the Beijing Xinyuan Hotel to hear lectures by rheumatologists from China as well as invited speakers from around the world. I have attended few meetings where the energy was so high and the eagerness to learn so great.

While most of the international speakers had previously visited Beijing, the meeting was my first trip to China. To say the least, I was surprised by the city's modernity. Growing up in a very frosty time of the Cold War, China - usually called Red China or Communist China in the United States - was very much a forbidden country until Nixon thawed relationships with secret diplomacy, a ping-pong tournament and a memorable visit in 1972. I remain uncertain about the city's name because, during my lifetime, Beijing has also been called both Peking and Peiping. The images I have of modern China come mostly from the telecasts of the 2008 Olympics, although the NBC commentators seemed mostly interested in street food as if restaurants did not exist. I had few preconceived ideas of the real Beijing as opposed to the attractions I read about in 1000 Places to See Before You Die.

While China is a very old country, Beijing is a very new city. I would say that Beijing has the ambience of a boom town - but boom town is a misnomer for a megalopolis

*Correspondence: piset001@mc.duke.edu

Duke University Medical Center, 151G, Durham VA Medical Center, Durham, NC 27705, USA that has a population of about 20 million people and a land area of 6,500 square miles. About half the size of Belgium, Beijing makes Chicago look like a quaint little village with its neighborhoods of row houses. High-rise apartments and office buildings are everywhere as if the only direction to grow is up. Alas, a dense haze often covers the landscape, blotting the outline of some beautiful buildings and preventing appreciation of the sheer magnitude of the construction that has marked the explosive growth of Beijing in recent years.

Throughout the city, wide avenues and highways are dense with cars at all hours. Driving around for sightseeing, I was gratified (and indeed mystified) to see many cars with Buick on the name plate. Indeed, I probably saw more Buicks in Beijing than I do in Durham, North Carolina. There used to be an advert that said 'This is not your father's Buick.' I guess in China the advert says 'This is not your American's Buick.' That would be true since the car is the product of GM Shanghai, a joint venture of General Motors and CDAI. Actually, GM sells more cars in China than in the United States. Volkswagens, Hyundais and Audi are also frequent vehicles and far outnumber the bicycles and scooters I was expecting.

As a tourist attraction, the ultra-modern Birds Nest Olympics stadium with its gleaming lattice shell designed by Swiss architects now competes for attention with the ancient Great Wall, the Forbidden City and the Summer Palace. The Egg is another landmark and a great building. For those who delight in stirring architecture, I recommend Beijing Airport. Airports are not usual venues for sightseers since they call forth memories of long lines at immigration, canceled flights and lost luggage. Nevertheless, Beijing Airport is a spectacular structure that is filled with light from an undulating ceiling of windows. The outside roof is painted red, the Chinese symbol for good luck. If you go to Beijing, you of course visit the airport, perhaps discombobulated by the time-zone change. My recommendation is to rouse yourself awake and look at the building and not just stumble through it.

Like China, rheumatology research is experiencing a boom and is on the go. As talks at the IFRA demonstrated clearly, modern science moves with incredible speed and is producing voluminous data at a dizzying pace. The 
technology keeps getting better and better, the analysis of the pathogenesis more and more precise. (Alas, while I saw the data presented by speakers from China, I will have to confine my comments to those talks that were in English. I want to make sure that my comments are reasonably correct and apologize to those whose work I cannot describe with confidence.)

Still in the midst of the genetics revolution, rheumatology is entering the epigenetics revolution. Studies by Professor Steffen Gay of Zurich and Professor Gary Firestein of San Diego described extraordinary progress in unraveling epigenetic changes in fibroblasts that may endow these cells with an invasive phenotype. These changes can result from base methylation reactions that lead to long-term changes in gene function; interestingly, some epigenetic changes may be transmitted through the generations. In this talk, Professor Gay raised the possibility of therapies to undo epigenetic modifications, including some agents that I can purchase at my local GNC store. Discussing another element of gene regulation, Professor Iain McInness of Glasgow illustrated how miRNA can regulate key events in immune activation. miRNA can be a target for therapy, as illustrated by findings from Professor Gay and colleagues on the use of antagomirs in a pulmonary hypertension model.

Modern technology is also providing new insights into B-cell abnormalities that underpin autoimmunity in rheumatoid arthritis (RA). Presenting a study of antibodies to citrullinated proteins (ACPA), Professor Klareskog described the extraordinary commitment of synovial B cells to ACPA production, with about $30 \%$ of these cells pumping out immunoglobulin to drive events in synovial inflammation. ACPA may have some unexpected roles in pathogenesis since, as Professor Klareskog showed, antibodies to citrullinated vimentin may trigger osteoclastogenesis, perhaps driving bone loss that is so characteristic of RA. Complementing these talks was a presentation by Professor Joachim Kalden of Erlangen on the treatment of autoimmunity with bortezemib, a proteasome inhibitor that can interfere with plasma cells. In both murine models as well as early studies on patients with lupus, this agent can reduce antiDNA levels; effects on protective antibodies are of course a concern and will be closely watched as this therapy advances.

A presentation by Professor Ed Keystone of Toronto illustrated striking progress on the clinical front. Professor Keystone addressed two main topics, highlighting recent presentations from the European League Against Rheumatism meeting in Berlin. Two messages are clear. The first is that, in head-to-head trials, agents that differ in action can lead to similar clinical responses. Adalimumab and subcutaneous abatacept thus showed comparable efficacy; reference to prior trials suggests that the effects of subcutaneous abatacept may differ from those of the intravenous formulation with respect to the time course and magnitude of the response. The results of the head-to-head trials are also surprising in view of an impression that the efficacy of co-stimulatory blockade may differ from that of TNF blockade. These studies raise the question of why agents that attack fundamentally different cellular pathways act so similarly. While current terminology emphasizes the concept of targeted therapy, the action of treatments may converge so that the same bull's eye is hit even if the arrows come from different directions.

A second message of Professor Keystone's talks relates to remission. As the data he presented showed, treatment of RA with current agents and strategies (that is, treat to target and tight control) can induce remission in a significant number of patients as defined by well-established outcome measures. Furthermore, as he reported in patients achieving remission with a combination approach, elimination of a biological agent does not lead to relapse in many patients, with remission sustained at least over months. In the words of Professor Keystone, this is a game changer.

I think that the frequency of remission in recent clinical studies has caught many rheumatologists off guard. RA has long been conceptualized as a chronic, even relentless, disease with changes (?epigenetic) in synoviocytes leading to joint destruction even in the absence of inflammation. Interpretation of these clinical studies is, of course, dependent on the definition of remission and the extent of subclinical synovitis and radiological progression that may occur in a patient in whom arthritis seems quiescent.

Outcomes researchers will have ample opportunity to debate the criteria for remission and which composite measures (Disease Activity Score, Clinical Disease Activity Index, Simplified Disease Activity Index, Boolean), and their components, are most informative and reliable. I sometimes think rheumatologists do not really know how to quantify disease activity, for either clinical or research purposes, especially when inflammation is low. In my own clinical practice, I have thought that joint tenderness is important to this determination although Professor Keystone, an expert with decades of experience, gave the nod to joint swelling as a measure of active disease. During a discussion session, I asked Professor Keystone about his approach to assess swelling. He said ballottement of joint swelling is key, showing how he squeezes a joint with his fingers to determine its character and the presence of inflammation. If rheumatologists have to rely on ballottement to make crucial decisions to start or stop drugs, I have my concerns. Given the power and elegance of today's science, some biomarker or imaging modality must be out there to help 
with decision-making and tell whether the fire of inflammation smolders or has been successfully doused.

In addition to its importance clinically, the phenomenon of remission should drive inquiry into disease mechanisms, providing a unique setting to explore critical events in pathogenesis. Much research in rheumatology now focuses on preclinical autoimmunity, the time prior to the onset of clinical symptoms, in which immune cell abnormalities (for example, ACPA expression, cytokine production) are revving up for their full onslaught. With remission, there is perhaps now a state of postclinical autoimmunity in which signs and symptoms abate.

What is going on in patients with remission? Consider two examples. ACPA have a close relationship to RA, with some data, including animal studies, pointing to a direct role in joint inflammation. If ACPA titers do not change much during remission, then their role in pathogenesis is up for grabs. Perhaps during remission, ACPA specificity shifts in some subtle but significant way to nonpathogenic species. Since these antibodies emanate from long-lived plasma cells, however, I doubt such a change. Alternatively, an antigen required for immune complex formation may have disappeared during remission or, more probably, the downstream effectors have been quieted.

A second example relates to epigenetics. Many current studies on the epigenetic modification of fibroblasts involve operative specimens obtained at the time of replacement joint surgery. Synoviocytes in such tissues have been subject to years (?decades) of inflammation, the assault of biomechanical stress and even a slug or two of intra-articular glucocorticoids to go along with years of disease-modifying antirheumatic drugs. Until the advent of remission, it would be difficult to know which of these changes is primary or secondary - although, as Dr Firestein showed, IL-1 can affect DNA methylation. Now, with remission, epigenetic imprinting can be studied in a new way, although obtaining samples of synovium during remission may be challenging unless techniques for easy tissue retrieval become available.

The IFRA occurred in the midst of the US presidential election although, with current politics, it seems we are always in the midst of a presidential election. Talk of 2016 is already heating up. Palin versus Clinton? Whatever the outcome of the 2012 contest - red or blue - the prospects for the National Institutes of Health budget look bleak gray if not black. Given the drive to shrink the federal budget and blot away red ink, stagnant funding may be the best we can do although genuine cutbacks may occur. Cutbacks on research now would be a great tragedy since technology is leading to unprecedented discoveries that can be translated into treatment advance. I wish some of our politicians would have attended the IFRA to hear lectures by Chinese investigators or to speak to Chinese students whose numbers have swelled with the influx of government money. Those politicians would have seen what a commitment to building research can accomplish in terms of innovation, economic growth and the inspiration provided to young people who are anxious to discuss the effects of IL-2 on regulatory T cells or the role of STING in the immune response to DNA in lupus.

According to de Tocqueville, the genius of America came from the pursuit of 'self-interest properly understood.' China seems to be taking a different path, however. Practically and philosophically, it seems that China wants to pursue national interest properly understood. In either system, proper understanding must balance the interests of the individual and those of the state, always a great challenge. China is an old country and America is a young one, but both are struggling to find a balance consistent with their histories and cultures. Given the importance of US and Chinese economies in the world, there will be many onlookers to this great political process.

I was honored to attend the IFRA and witness the extraordinary accomplishments of China in rheumatology research. It was a truly wonderful occasion of fellowship and cooperation, and I was excited to meet and toast new friends with potently delicious Chinese wine that had a strong resemblance to what in North Carolina we call white lightning. I look forward to many more years of international cooperation as we work together to advance rheumatology research and improve the health of people of the world properly understood.

Gan bei!

\section{Abbreviations}

ACPA, antibodies to citrullinated proteins; IFRA, 4th International Forum on Rheumatoid Arthritis; IL, interleukin; miRNA, microRNA; RA, rheumatoid arthritis; STING, stimulator of interferon genes; TNF, tumor necrosis factor.

\section{Competing interests}

The author declares that he has no competing interests.

\section{Published: 27 September 2012}

\section{Suggested reading}

1. Barber GN: Cytoplasmic DNA innate immune pathways. Immunol Rev 2011, 243:99-108.

2. Boyman $\mathrm{O}$, Sprent J: The role of interleukin-2 during homeostasis and activation of the immune system. Nat Rev Immuno/ 2012, 12:180-190.

3. Brock M, Samillan VJ, Trenkmann M, Schwarzwald C, Ulrich S, Gay RE, Gassmann M, Ostergaard L, Gay S, Speich R, Huber LC: Antagomir directed against miR-20a restores functional BMPR2 signalling and prevents vascular remodeling in hypoxia-induced pulmonary hypertension. Eur Heart J 2012. [Epub ahead of print]

4. Felson DT, Smolen JS, Wells G, Zhang B, van Tuyl LH, Funovits J, Aletha D, Allaart CF, Bathon J, Bombardieri S, Brooks P, Brown A, Matucci-Cerinic M, Choi H, Combe B, de Wit M, Dougados M, Emery P, Furst D, Gomez-Reino J, Hawker G, Keystone E, Khanna D, Kirwan J, Kvien TK, Landewé R, Listing J, Michaud K, Martin-Mola E, Montie P, et al:; American College of Rheumatology; European League Against Rheumatism: American College of Rheumatology/European League Against Rheumatism provisional definition of remission in rheumatoid arthritis for clinical trials. Arthritis 
Rheum 2011, 63:573-586

5. Harris U, Georgess D, Bang H, Bozec A, Axmann R, Ossipova E, Jakobsson PJ, Baum W, Nimmerjahn F, Szarka E, Sarmay G, Krumbholz G, Neumann E, Toes R, Scherer HU, Catrina Al, Klareskog L, Jurdic P, Schett G: Induction of osteoclastogenesis and bone loss by human autoantibodies against citrullinated vimentin. J Clin Invest 2012, 122:1791-1802.

6. Hughes-Austin JM, Deane KD, Derber LA, Kolfenbach JR, Zerbe GO, Sokolove J, Lahey LJ, Weisman MH, Buckner JH, Mikuls TR, O'Dell JR, Keating RM, Gregersen PK, Robinson WH, Holers VM, Norris JM: Multiple cytokines and chemokines are associated with rheumatoid arthritis-related autoimmunity in first-degree relatives without rheumatoid arthritis: Studies of the Aetiology of Rheumatoid Arthritis (SERA). Ann Rheum Dis 2012. [Epub ahead of print]

7. Keystone EC, Smolen J, van Riel P: Developing an effective treatment algorithm for rheumatoid arthritis. Rheumatology 2012, 51:v48-v54.

8. Nakano K, Whitaker JW, Boyle DL, Wang W, Firestein GS: DNA methylome signature in rheumatoid arthritis. Ann Rheum Dis 2012. [Epub ahead of print]
9. Neubert K, Meister S, Moser K, Weisel F, Maseda D, Amann K, Wiethe C, Winkler TH, Kalden JR, Manz RA, Voll RE: The proteasome inhibitor bortezomib depletes plasma cells and protects mice with lupus-like disease from nephritis. Nat Med 2008, 14:748-755.

10. Sokolove J, Bromberg R, Deane KD, Lahey LJ, Derber LA, Chandra PE, Edison JD, Gilliland WR, Tibshirani RJ, Norris JM, Holers VM, Robinson WH: Autoantibody epitope spreading in the pre-clinical phase predicts progression to rheumatoid arthritis. PLoS One 2012, 7:e35296.

11. Studenic P, Smolen JS, Aletaha D: Near misses of ACR/EULAR criteria for remission: effects of patient global assessment in Boolean and indexbased definitions. Ann Rheum Dis 2012, 71:1702-1705.

doi:10.1186/ar4036

Cite this article as: Pisetsky DS: 4th International Forum on Rheumatoid Arthritis: Great Times Near the Great Wall. Arthritis Research \& Therapy 2012,

14:125. 